\title{
CT Coronary Angiography Versus Conventional Invasive Coronary Angiography - The View of the Referring Physician
}

\section{CT-Koronarangiografie versus konventionelle invasive Koronarangiografie - Die Sicht der Zuweiser}

Authors

Affiliation
M. H. Maurer, E. Zimmermann, B. Hamm, M. Dewey

Department of Radiology, Charité - Universitätsmedizin Berlin

\author{
Key words \\ - cardiac \\ - CT coronary angiography \\ - survey \\ - referring physician \\ - patient satisfaction
}

received $\quad 26.10 .2013$

accepted 31.3.2014

Bibliography

Dol http://dx.doi.org/

10.1055/s-0034-1366432

Published online: 23.4.2014

Fortschr Röntgenstr 2014; 186:

1102-1110 @ Georg Thieme

Verlag KG Stuttgart - New York .

ISSN 1438-9029

\section{Correspondence}

\section{Dr. Martin H Maurer}

Department für Diagnostische, Interventionelle und

Pädiatrische Radiologie,

Universitätsspital Bern,

Inselspital

Freiburgstr. 10

3010 Bern

Switzerland

Tel.: ++ 41/31/632 7180

martin.maurer@insel.ch

\section{Zusammenfassung}

$\nabla$

Zielsetzung: Evaluation der bisherigen Erfahrungen der lokalen Zuweiser mit dem Verfahren der Computertomografie (CT)-Koronarangiografie (CCTA) im praktischen Alltag.

Material und Methoden: Ein 25 Fragen umfassender Fragebogen wurde an 179 ärztliche Kollegen versandt, die bisher insgesamt 1986 Patienten für CT-Koronarangiografien überwiesen hatten. Gefragt wurde nach den bisherigen Erfahrungen mit CT-Koronarangiografien, der Indikationsstellung für eine Koronardiagnostik (z. B. Ausschluss einer koronaren Herzerkrankung ([KHK]) und der bisherigen Praxis bei der Überweisung für eine nicht-invasive CCTA oder eine invasive Katheterangiografie. Zusätzlich sollten beide diagnostischen Verfahren aus der Sicht der Überweiser und anhand der geschilderten Erfahrungen der Patienten beurteilt werden.

Ergebnisse: 53 Fragebogen konnten ausgewertet werden (30\% Auswerterate; entsprachen mehr als $72 \%$ der überwiesenen Patienten). 94\% dieser Zuweiser sahen in der CT-Koronarangiografie einen konkreten Mehrwert in der Patientenbehandlung, wobei $87 \%$ mit der Befunderstellung zufrieden oder sehr zufrieden waren. Auf einer 5-stufigen Skala hielten die Zuweiser zum Ausschluss einer KHK bei niedriger Prätestwahrscheinlichkeit die CT-Koronarangiografie $(4,2 / 5)$ und die konventionelle Koronardiagnostik bei einem akuten Koronarsyndrom (1,6/5) als besser geeignet, beide Verfahren als etwa gleichwertig in der Verlaufskontrolle nach koronarem Bypass $(3,0 / 5)$. Grund für eine Nichteignung für die CT-Diagnostik war vor allem eine berichtete Platzangst oder ein fehlender Sinusrhythmus. Die Höhe der Strahlenexposition für eine CCTA wurde von nur $42 \%$ der Zuweiser richtig eingeschätzt. $90 \%$ der Zuweiser berichteten, dass ihre Patienten die CT des Herzens insgesamt positiv oder neutral bewerteten, wobei $87 \%$ der Zuweiser, deren Pa-

\section{Abstract \\ $\nabla$}

Purpose: Assessment of experience gained by local referring physicians with the procedure of coronary computed tomographic angiography (CCTA) in the everyday clinical routine.

Materials and Methods: A 25-item questionnaire was sent to 179 physicians, who together had referred a total of 1986 patients for CCTA. They were asked about their experience to date with CCTA, the indications for coronary imaging, and their practice in referring patients for noninvasive CCTA or invasive catheter angiography.

Results: 53 questionnaires (30\%) were assessable, corresponding to more than $72 \%$ of the patients referred. Of the referring physicians who responded, $94 \%$ saw a concrete advantage of CCTA in the treatment of patients, whereby $87 \%$ were 'satisfied' or 'very satisfied' with the reporting. For excluding coronary heart disease (CHD) where there was a low pre-test probability of disease, the physicians considered CCTA to be superior to conventional coronary diagnosis ( 4.2 on a scale of $1-5)$ and vice versa for acute coronary syndrome (1.6 of 5). The main reasons for unsuitability of CCTA for CT diagnosis were claustrophobia and the absence of a sinus rhythm. The level of exposure to radiation in CCTA was estimated correctly by only $42 \%$ of the referring physicians. $90 \%$ of the physicians reported that their patients evaluated their coronary CT overall as 'positive' or 'neutral', while $87 \%$ of the physicians whose patients had undergone both procedures reported that the patients had experienced CCTA as the less disagreeable of the two.

Conclusion: CCTA is accepted by the referring physicians as an alternative imaging procedure for the exclusion of CHD and received a predominantly positive assessment from both the referring physicians and the patients. 
tienten bereits beide Verfahren erhalten hatten, aus Patientensicht von einer als weniger unangenehm empfundenen CCTA berichteten.

Schlussfolgerung: Die CT-Koronarangiografie stellt ein von den Zuweisern akzeptiertes bildgebendes Verfahren zum Ausschluss einer KHK dar, welches von den Zuweisern und Patienten überwiegend positiv bewertet wird.

Kernaussagen:

- Ein hoher Anteil der Zuweiser hat bisher gute Erfahrungen mit der nicht-invasiven CT-Koronarangiografie gemacht.

- Die CT-Koronarangiografie stellt ein von den Zuweisern akzeptiertes alternatives bildgebendes Verfahren zum Ausschluss einer koronaren Herzkrankheit dar.

- Die nicht-invasive CT-Koronarangiografie wird von Patienten im direkten Vergleich mit der invasiven konventionellen Koronarangiografie als weniger unangenehm empfunden.

\section{Introduction}

General practitioners and internists wishing to perform diagnosis of patients with suspected coronary heart disease (CHD) nowadays have a choice between conventional coronary angiography (cardiac catheterization) and noninvasive computed-tomographic (CT) angiography of the coronary arteries (coronary CT angiography, CCTA). This is due above all to the rapid technical development of multi-slice CT, which has elevated CCTA to an alternative imaging method with a value equal to that of the invasive catheterization procedure [ $1-3]$. It is to be noted that CCTA has a high negative predictive value and is therefore especially suited for the exclusion of CHD among patients with a low to medium pre-test probability of CHD [4-6]. Moreover, thanks to the most recent technical improvements - such as rapid table movement in dual-source CT and the use of multi-slice scanners with awide-area detector CCTA is today associated with a much lower exposure to radiation than conventional coronary angiography is $[7,8]$. In contrast, interventional catheter angiography remains the "gold standard" for the evaluation of luminal obstructions in highly calcified vessel segments and allows direct interventional procedures.

However, to ensure the best suitable imaging procedure for patients, providers of CCTA examinations - who are also in mutual competition - need to maintain a good collaborative relationship with referring physicians. Unlike hospital physicians, general practitioners and internists often have no direct contact with radiology departments and do not take part in clinical/radiological case discussions, so that frequently the only contact between the radiologist and the referring physician is the communication of the diagnostic result. There can be real added value for the referring physician in the manner and comprehensibility of the diagnostic result, and support in making the diagnosis [9-13].

The aim of this survey was to evaluate the experience of referring physicians to date with the relatively new diagnostic technique of CCTA, and to assess its value in the clinical routine.

\section{Methods}

$\nabla$

A 25-item questionnaire ( Table 1) was sent in March 2010 to 179 physicians who had referred a total of 1986 patients for coronary CT at our hospital in 2008 and 2009 [14]. The first part of the questionnaire dealt with the professional background of the referring physician, including his/her specific training in conven-
Key points:

- A high percentage of referring physicians had positive experiences with noninvasive CT coronary angiography (CCTA) so far.

- CCTA is accepted by referring physicians as an alternative imaging procedure for the exclusion of coronary heart disease.

- Noninvasive CT coronary angiography is perceived by patients in direct comparison with conventional invasive coronary angiography as less disagreeable.

Citation Format:

- Maurer MH, Zimmermann E, Hamm B et al. CT Coronary Angiography Versus Conventional Invasive Coronary Angiography - The View of the Referring Physician. Fortschr Röntgenstr 2014; 186: 1102-1110

tional and CT coronary angiography and previous experience with the two diagnostic methods. It was asked how satisfied they were with CCTA overall when they referred patients to our center and how they estimated the mean radiation exposure. The second part contained questions about the indication for angiography (e.g. exclusion of CHD or coronary anomalies, progress monitoring in patients with coronary stents or bypasses) and their previous practice in referring patients for one or the other angiographic procedure in consideration of the pre-test probability of CHD, the results of other diagnostic procedures (e.g. ECG, echocardiography) and the patient's own choice. In the third and final part, the referring physicians were asked to assess the two diagnostic procedures, both from their own viewpoint and on the basis of their patients' accounts of their experience.

The data obtained from the questionnaires and their evaluation were handled with the software MS Excel (Microsoft, Redmond, WA, USA) and SPSS Version 12.0 (SPSS Inc., Chicago, USA). Continuous and categorical variables were given as absolute numerical values, percentages, means, medians and minima/maxima as appropriate.

\section{Results}

$\nabla$

The questionnaire was completed and returned by 56 referring physicians. 3 questionnaires were incomplete, so that 53 (30\% of the 179 sent out) were included in the evaluation. Of these, 6 were returned anonymously. The remaining 47 (89\%) participants had referred a total of 1431 patients ( $72.1 \%$ of the 1986 patients referred to us in 2008 and 2009).

\section{Physicians and their experience with coronary angiography}

The specialization, the employment, and the experience of coronary diagnosis with coronary CT angiography or conventional angiography of the 53 participants are presented in 0 Table 2. Up to 2006, 16 (30\%) of the participants had experience with coronary diagnosis by CT or had referred patients for this. 6 of the participants (11\%) had referred patients since 2007, 15 (28\%) since 2008, 11 (21\%) since 2009 and another 2 (4\%) since 2010 (3 made no statement). The general level of satisfaction of the referring physicians with the CCTA carried out in our hospital is represented in $\bullet$ Fig. 1. For cardiac CT investigations, 33 participating physicians (62\%) referred patients to our center only, while 20 participants (38\%) also had experience with other centers. Of 
Table 1 25-item questionnaire to assess the experience of referring physicians with CT coronary angiography to date.

Tab. 1 Verwendeter Fragebogen mit 25 Fragen zur Befragung der Zuweiser hinsichtlich deren bisheriger Erfahrungen mit der CT-Koronarangiografie.

\begin{tabular}{|c|c|c|}
\hline $\begin{array}{l}\text { question } \\
\text { no. }\end{array}$ & question & possible answers \\
\hline 1 & What is the nature of your work as a physician? & $\begin{array}{l}\text { own practice/employee in a community health center/state-funded } \\
\text { hospital/private hospital/university hospital }\end{array}$ \\
\hline 2 & What is your specialization? & $\begin{array}{l}\text { specialist in internal medicine and general medicine/specialist in inter- } \\
\text { nal medicine with other specialization/heart surgery/vascular surgery/ } \\
\text { other }\end{array}$ \\
\hline 3 & $\begin{array}{l}\text { In what year did you start using coronary CT diagnosis or refer- } \\
\text { ring patients for such diagnoses? }\end{array}$ & (year) \\
\hline 4 & $\begin{array}{l}\text { Have you received formal training (e. g. qualification as specia- } \\
\text { list, seminar, workshop, etc.) in the assessment of conventional } \\
\text { coronary angiography? }\end{array}$ & yes/no \\
\hline 5 & $\begin{array}{l}\text { Have you received formal training (e. g. qualification as specia- } \\
\text { list, seminar, workshop, etc.) in the assessment of coronary CT } \\
\text { angiography? }\end{array}$ & yes/no \\
\hline 6 & $\begin{array}{l}\text { How satisfied are you with the coronary CT diagnoses performed } \\
\text { at our hospital? }\end{array}$ & $\begin{array}{l}\text { very satisfied/satisfied/moderately satisfied/dissatisfied/no assess- } \\
\text { ment possible }\end{array}$ \\
\hline 7 & $\begin{array}{l}\text { Do you have experience with coronary CT diagnoses at other } \\
\text { centers? }\end{array}$ & $\begin{array}{l}\text { yes/no } \\
\text { If 'yes': Quality was similar/quality in our hospital was better/quality in } \\
\text { the other hospital was better/until now no center has been satisfactory. }\end{array}$ \\
\hline 8 & $\begin{array}{l}\text { On the whole do you regard coronary } \mathrm{CT} \text { as useful in the context } \\
\text { of providing health care for your patients? }\end{array}$ & $\begin{array}{l}\text { yes/no } \\
\text { If 'yes' (more than one answer can be indicated): It offers a concrete } \\
\text { advantage in the treatment of patients/the presence of coronary heart } \\
\text { disease (CHD) can be reliably excluded/the diagnosis and the imaging } \\
\text { material can be used to explain to the patient his/her state of health and } \\
\text { the need for treatment. } \\
\text { If 'no' (more than one answer can be indicated): The diagnostic proce- } \\
\text { dure often conveys little or no additional advantage for the treatment/ } \\
\text { many patients had coronary stenoses so that CHD could not be exclud- } \\
\text { ed/the diagnostic procedures were not technically satisfactory/the ra- } \\
\text { diological finding was not comprehensible. }\end{array}$ \\
\hline 9 & $\begin{array}{l}\text { In your estimation, approximately how many conventional thor- } \\
\text { acic X-rays does the radiation of a single 64-cell coronary CT } \\
\text { angiography correspond to? }\end{array}$ & $\begin{array}{l}\text { about as much as } 1 \text { thoracic } X \text {-ray/about } 10 \text { thoracic } X \text {-rays/about } \\
50 \text { - } 200 \text { thoracic } X \text {-rays/about } 500-1000 \text { thoracic } X \text {-rays/more } \\
\text { than } 5000 \text { thoracic } X \text {-rays }\end{array}$ \\
\hline 10 & $\begin{array}{l}\text { Which of the following questions do you feel could best be an- } \\
\text { swered by cardiac CT or by conventional coronary angiography? } \\
\text { 1. Suspicion of CHD with high pre-test probability (e. g. typical } \\
\text { complaints and/or positive result of physical performance } \\
\text { tests). } \\
\text { 2. Exclusion of CHD with low to medium pre-test probability } \\
\text { (e. g. atypical complaints and/or contradictory results of } \\
\text { physical performance tests). } \\
\text { 3. Progress monitoring for patients with coronary bypass. } \\
\text { 4. Analysis of cardiac function as part of coronary } \\
\text { CT angiography. } \\
\text { 5. Analysis of cardiac function on its own. } \\
\text { 6. Exclusion of coronary anomalies. } \\
\text { 7. Progress monitoring for patients with coronary stents, de- } \\
\text { pending on the stent diameter (e. g. only if at least } 3.5 \text { mm). } \\
\text { 8. Progress monitoring for patients with coronary stents, in- } \\
\text { dependent of the stent diameter. } \\
\text { 9. Acute coronary syndrome or unstable angina pectoris. } \\
\text { 10. Exclusion of CHD in screening of clinically healthy patients. } \\
\text { 11. Simultaneous exclusion of CHD, artery dissection and pul- } \\
\text { monary embolism ("triple rule-out"). } \\
\text { 12. Analysis of myocardial vitality and perfusion. }\end{array}$ & $\begin{array}{l}\text { answer for each question on a scale from } 1 \text { to } 5 \\
\text { ( } 5=\text { coronary } C T \text { angiography much more suitable; } 3 \text { = the two proce- } \\
\text { dures are of identical value; } 1=\text { conventional coronary angiography } \\
\text { much more suitable) }\end{array}$ \\
\hline 11 & $\begin{array}{l}\text { For what pre-test probability (= estimated probability that a pa- } \\
\text { tient is suffering from a given disease) do you regard coronary } \\
\text { CT angiography as suitable for suspected CHD? (More than one } \\
\text { answer can be indicated.) }\end{array}$ & below $25 \% /$ between $25 \%$ and $50 \% /$ between $50 \%$ and $75 \%$ /above $75 \%$ \\
\hline 12 & $\begin{array}{l}\text { What procedure do you generally adopt for referring a patient for } \\
\text { coronary angiography? }\end{array}$ & $\begin{array}{l}\text { I still prefer invasive coronary angiography/I refer the patient for non- } \\
\text { invasive coronary CT angiography if possible/after explaining both pro- } \\
\text { cedures I let the patient decide. }\end{array}$ \\
\hline
\end{tabular}




\begin{tabular}{|c|c|c|}
\hline $\begin{array}{l}\text { question } \\
\text { no. }\end{array}$ & question & possible answers \\
\hline 13 & $\begin{array}{l}\text { What percentage of your patients for whom diagnostic coronary } \\
\text { angiography is indicated do you send for CT or conventional cor- } \\
\text { onary angiography? (Please state numbers that add up to } 100 \% \text {.) }\end{array}$ & (statement of proportions) \\
\hline 14 & $\begin{array}{l}\text { If your patients had a choice between conventional and CT an- } \\
\text { giography (assuming equal diagnostic accuracy), which method } \\
\text { would they be likely to choose? (Please state numbers that add } \\
\text { up to } 100 \% \text {.) }\end{array}$ & (statement of proportions) \\
\hline 15 & $\begin{array}{l}\text { In your opinion, which test procedures should be conducted be- } \\
\text { fore CT angiography in cases where there is suspicion of CHD? } \\
\text { (More than one answer can be indicated.) }\end{array}$ & $\begin{array}{l}\text { resting ECG/stress ECG/echocardiography/stress echocardiography/ } \\
\text { myocardial scintigraphy/determination of troponin and CK-MB/ } \\
\text { no procedure necessary }\end{array}$ \\
\hline 16 & $\begin{array}{l}\text { What percentage of your patients would you estimate is unsui- } \\
\text { table for coronary CT angiography because of a lack of a sinus } \\
\text { rhythm (needed for most computer-aided tomography)? }\end{array}$ & (free space for statement of percentage) \\
\hline 17 & $\begin{array}{l}\text { What percentage of your patients would you estimate is unsui- } \\
\text { table for coronary CT angiography because of an inability to } \\
\text { perform a breath-hold for at least } 10 \text { seconds (as needed for } \\
\text { most computer-aided tomography)? }\end{array}$ & (free space for statement of percentage) \\
\hline 18 & $\begin{array}{l}\text { What percentage of your patients would you estimate is unsui- } \\
\text { table for coronary CT angiography for other reasons? }\end{array}$ & $\begin{array}{l}\text { (free space for statement of percentage and for free text stating } \\
\text { reasons) }\end{array}$ \\
\hline 19 & $\begin{array}{l}\text { Have any of your patients ever refused a referral that you offered } \\
\text { for coronary CT angiography? }\end{array}$ & $\begin{array}{l}\text { yes/no } \\
\text { If 'yes', why? - Fear of exposure to radiation/fear of possible finding/ } \\
\text { claustrophobia/negative experience with earlier CT diagnoses/space } \\
\text { for free text stating other reasons. }\end{array}$ \\
\hline 20 & $\begin{array}{l}\text { What is the impression generally reported back to you by pa- } \\
\text { tients after cardiac CT? }\end{array}$ & $\begin{array}{l}\text { Mostly positive/procedure was largely tolerable/the patient reported } \\
\text { significant discomfort/no assessment possible. }\end{array}$ \\
\hline 21 & $\begin{array}{l}\text { Do you have any patients who had already undergone conven- } \\
\text { tional coronary angiography and have now also undergone car- } \\
\text { diac CT? }\end{array}$ & $\begin{array}{l}\text { yes/no } \\
\text { If 'yes': What impression do these patients give regarding the tolerabil- } \\
\text { ity of coronary CT angiography? } \\
\text { Coronary CT angiography was significantly less disagreeable/the two } \\
\text { procedures were equally disagreeable/conventional angiography was } \\
\text { less disagreeable. }\end{array}$ \\
\hline 22 & $\begin{array}{l}\text { What percentage of patients did you have to refer for conven- } \\
\text { tional coronary angiography after coronary CT angiography? }\end{array}$ & $\begin{array}{l}\text { below } 5 \% / \text { between } 5 \% \text { and } 20 \% / \text { between } 20 \% \text { and } 40 \% / \text { between } 40 \% \\
\text { and } 60 \% \text { /between } 60 \% \text { and } 80 \% \text { /above } 80 \%\end{array}$ \\
\hline 23 & $\begin{array}{l}\text { What was the percentage of your patients for whom coronary CT } \\
\text { angiography was adequate, making it possible to dispense with } \\
\text { conventional coronary angiography? }\end{array}$ & $\begin{array}{l}\text { below } 5 \% / \text { between } 5 \% \text { and } 20 \% / \text { between } 20 \% \text { and } 40 \% / \text { between } 40 \% \\
\text { and } 60 \% / \text { between } 60 \% \text { and } 80 \% / \text { above } 80 \%\end{array}$ \\
\hline 24 & $\begin{array}{l}\text { Would you regard it as useful if we enclosed individual CT recon- } \\
\text { structions with significant findings along with the letter stating } \\
\text { the findings? }\end{array}$ & $\begin{array}{l}\text { yes/no } \\
\text { If 'yes': The finding would be easier to comprehend and reconstruct/the } \\
\text { finding would be easier to explain to the patient. } \\
\text { If 'no': The text stating the finding is sufficient/the additional complex- } \\
\text { ity of the finding including the images would take up too much time/the } \\
\text { therapeutic strategy would not change significantly. }\end{array}$ \\
\hline 25 & $\begin{array}{l}\text { How high do you believe the cost ratio between coronary CT } \\
\text { angiography and conventional diagnostic angiography is? }\end{array}$ & (space for statement of ratio) \\
\hline
\end{tabular}

these, 16 (80\%) assessed the quality as similar, while 2 (10\%) found the quality at our hospital and $1(5 \%)$ the quality at another hospital to be significantly better (no comment by 1 participant, $5 \%)$.

Of all participating physicians, 94\% (50/53) regarded CCTA as on the whole useful in patient care, stating that it conveyed a concrete advantage for treatment $(27 / 50,54 \%)$, that it could reliably exclude CHD (19/50, 38\%), or that the image material and the finding could more clearly inform the patient about his/her state of health $(14 / 50,28 \%)$ or about the need for treatment $(17 / 50$, $34 \%$, multiple answers possible). Two participants regarded the result of the procedure as conveying no substantive additional value, and two complained that many patients also had coronary stenoses that necessitated a further referral for conventional coronary angiography. The exposure to radiation associated with coronary CT angiography with a 64-line computer tomograph was estimated by 7 referring physicians (13\%) as being identical to that of a chest X-ray while 19 (36\%) estimated it as being equivalent to 10 chest X-rays, 22 (42\%) said it was equivalent to $50-200$ und $2(4 \%)$ to $500-1000$ chest X-rays.

\section{Indication and referral for CCTA and conventional coronary angiography}

The individual items of the question of which indications might better be addressed by CCTA or by conventional coronary angiography, with the responses on a scale of $1-5$, are shown in - Fig. 2. The pre-test probability for which the referring physicians rated CCTA suitable to detect suspected CHD is shown in - Table 3. 24 of 53 (45\%) of the physicians continued to prefer invasive coronary angiography, and they only referred patients for CCTA on the patient's explicit wish. Conversely, 12/53 (22\%) preferred noninvasive CCTA, while $3 / 53(6 \%)$ informed patients 


\begin{tabular}{|c|c|c|}
\hline specialization ${ }^{1}$ & $\begin{array}{l}\text { number } \\
\text { of participants }\end{array}$ & percentage \\
\hline internal medicine & 28 & $54 \%$ \\
\hline $\begin{array}{l}\text { internists with further specialization } \\
\text { (cardiology, } n=11 \text {; infectious diseases, } n=1 \text { ) }\end{array}$ & 12 & $23 \%$ \\
\hline general practitioners & 6 & $12 \%$ \\
\hline heart surgeon & 1 & $2 \%$ \\
\hline $\begin{array}{l}\text { other specialization } \\
\text { (occupational medicine, neurology, gynecology, dermatology, practical physi- } \\
\text { cian, } n=1 \text { each) }\end{array}$ & 5 & $10 \%$ \\
\hline \multicolumn{3}{|l|}{ nature of work } \\
\hline own practice & 39 & $74 \%$ \\
\hline employee in a community health center & 6 & $11 \%$ \\
\hline university hospital & 4 & $8 \%$ \\
\hline private hospital & 2 & $4 \%$ \\
\hline more than one institution & 2 & $4 \%$ \\
\hline \multicolumn{3}{|c|}{ formal training in assessment of different diagnostic procedures of the coronary arteries } \\
\hline assessment of conventional angiograms & 15 & $28 \%$ \\
\hline assessment of $\mathrm{CT}$ coronary angiography & 3 & $6 \%$ \\
\hline no formal training in either procedure & 35 & $66 \%$ \\
\hline
\end{tabular}

Table 2 Specialization, employment, and experience of coronary diagnosis with CT or conventional angiography of the participants.

Tab. 2 Fachspezialisierung, Arbeitsverhältnisse und Erfahrung der Teilnehmer mit der Koronardiagnostik mittels konventioneller Angiografie und CT.

${ }^{1}$ statement from $\mathrm{n}=52$ participants (percent values rounded)

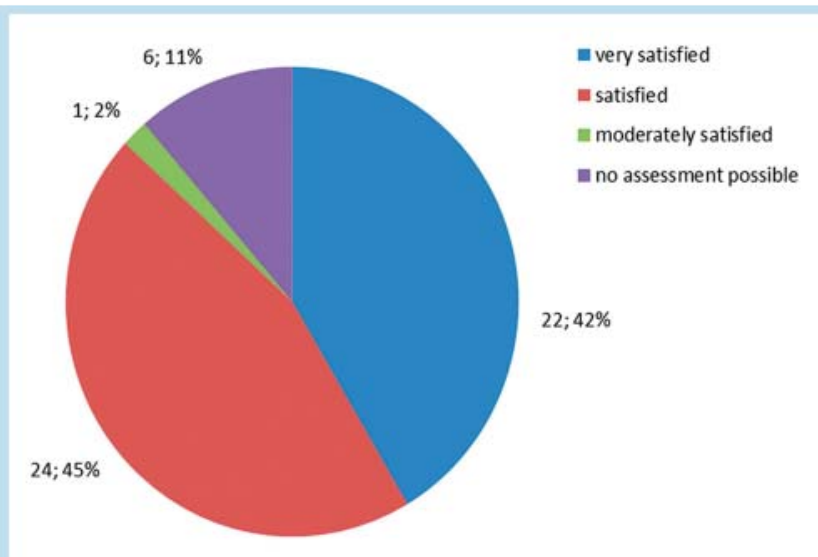

Fig. 1 Satisfaction of the referring physicians (number and percentage) with the CCTA carried out at our hospital ( $N=53$; none reported the category "dissatisfied").

Abb. 1 Zufriedenheit der Zuweiser (Anzahl und Prozentwerte) mit den in unserer Klinik durchgeführten CT-Koronarangiografie-Untersuchungen ( $n=53$, keiner der Überweiser war nicht zufrieden).

about both procedures and left the decision to the individual patient. Overall, $20 \%$ of patients needing a coronary examination were referred for $\mathrm{CT}$ and $80 \%$ for the conventional coronary diagnostic procedure (CT median 10\%, range $0-99 \%$; conventional procedure median $10 \%$, range $1-100 \%$ ). If patients were allowed to choose freely - assuming the procedures to be equal in diagnostic accuracy and that detailed advance information was given to the patients about both - the physicians stated that $67 \%$ would decide in favor of CCTA and $33 \%$ in favor of conventional coronary angiography (i. e., a ratio of 2:1 for CT; CT median $70 \%$, range $0-100 \%$; conventional coronary angiography median $30 \%$, range $0-100 \%)$.

The percentage of patients considered unsuitable for CCTA because of the absence of a sinus rhythm (which is required by most CT setups) was estimated on average to be $20 \%$ (median
$20 \%$, minimum $0 \%$, maximum $70 \%$ ) and the percentage considered unsuitable because of an inability to perform a breath-hold for at least 10 seconds was $12.4 \%$ (median $20 \%$, minimum $0 \%$, maximum $80 \%$ ). Further reasons for unsuitability for CCTA were claustrophobia (19 of the 53 physicians (36\%) stated a percentage of patients ranging from $5 \%$ to $20 \%$ ), intolerance of beta-blockers (3/53, 6\%; percentage of patients $5-10 \%)$, inadequate compliance $(2 / 53,4 \%$; percentage of patients $10-30 \%)$, intake of biguanides $(2 / 53,4 \%$; percentage of patients $5-20 \%)$ or fear of exposure to radiation (2/53, $4 \%$; percentage of patients $3-20 \%) .13$ of $53(25 \%)$ referring physicians reported having patients who refused to undergo CCTA. The reasons given for this were claustrophobia (8/13), fear of radiation exposure (5/13), negative experience with a previous CT examination (1/13) and the expense of CT $(2 / 13)$.

\section{Physicians' and patients' assessment of the} two diagnostic procedures

As reported by the referring physicians, the overall impression of patients with CCTA and of patients who had undergone both CCTA and a conventional coronary angiography is shown in - Fig. 3. The percentage of patients who after CCTA also needed a conventional angiography was below $5 \%$ for 23 referring physicians ( $44 \%$ ), between $5 \%$ and $20 \%$ for 9 physicians ( $17 \%$ ), between $20 \%$ and $40 \%$ for 6 physicians ( $11 \%$ ), between $40 \%$ and $60 \%$ for 8 physicians ( $15 \%$ ), between $60 \%$ and $80 \%$ for 3 physicians ( $6 \%$ ) and above $80 \%$ for a single physician. The percentage of patients for whom CCTA was adequate so that conventional angiography could be dispensed with was stated by 3 physicians ( $6 \%$ ) as more than $80 \%$, by $5(9 \%)$ as between $60 \%$ and $80 \%$, by $9(17 \%)$ as between $40 \%$ and $60 \%$, by $18(34 \%$ ) as between $20 \%$ and $40 \%$, by $15(28 \%)$ as between $5 \%$ and $20 \%$, and by $2(4 \%)$ as less than $5 \%$.

A substantial majority of the physicians $(44 / 53,83 \%)$ considered it to be useful if images of significant findings could be included with the findings statement as a CT reconstruction. This was for various reasons: it would make the finding easier to comprehend and to follow (25/44), it would make the finding easier to explain to the patient (30/44); or it would significantly affect the therapeutic strategy $(1 / 44)$. On the other hand, there were 8 physi- 
Suspicion of CHD with high pre-test probability (e.g. typical complaints and/or positive result of physical performance tests).

Exclusion of $\mathrm{CHD}$ with low to medium pre-test probability (e.g. atypical complaints and/or contradictory results of physical performance tests).

Progress-monitoring for patients with coronary bypass.

Analysis of cardiac function as part of coronary CT angiography.

Analysis of cardiac function on its own.

Exclusion of coronary anomalies.

Monitoring for patients with coronary stents, depending on the stent diameter (e.g. only if at least $3.5 \mathrm{~mm}$ ).

Monitoring for patients with coronary stents, independent of the stent diameter.

Acute coronary syndrome or unstable angina pectoris.

Exclusion of $\mathrm{CHD}$ in screening of clinically healthy patients.

Simultaneous exclusion of CHD, artery dissection and pulmonary embolism ("triple rule-out").

Analysis of myocardial vitality and perfusion.

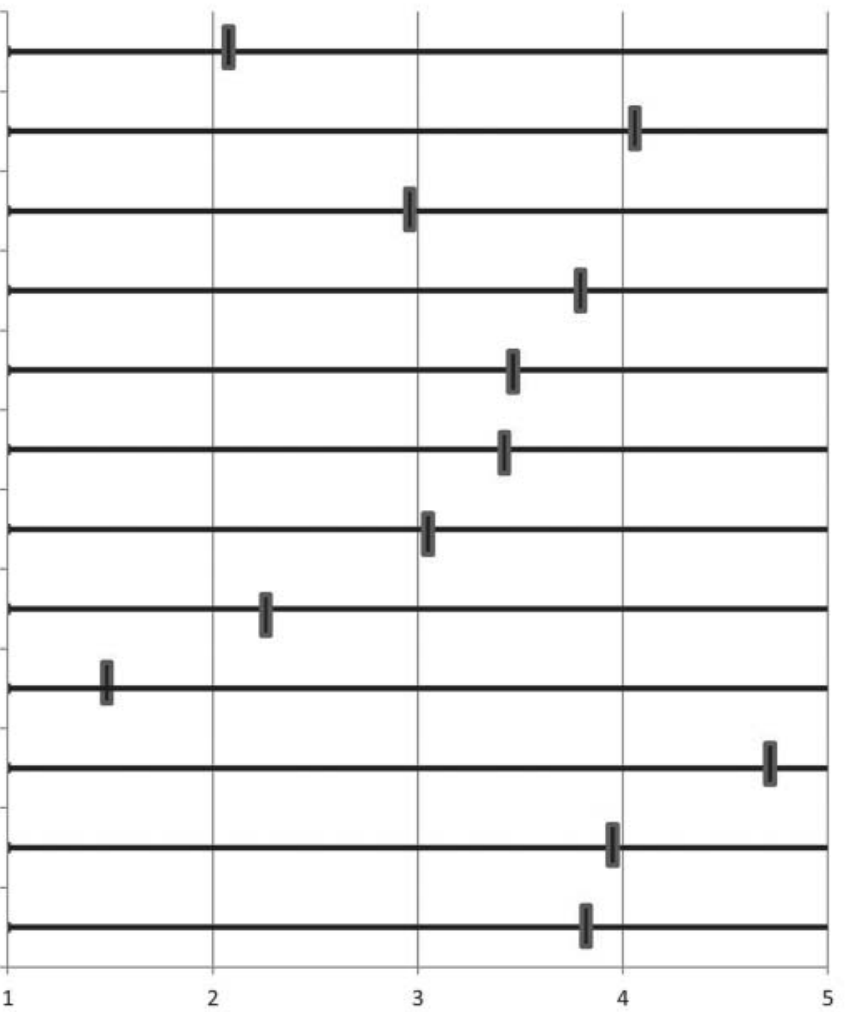

$$
\begin{aligned}
& 1=\text { conventional } \\
& \text { coronary angiography }
\end{aligned}
$$
much more suitable

\section{$3=$ both procedures are of identical value}

$5=\mathrm{C} T$ coronary angiography much more suitable
Fig. 2 Assessment by the participants of whether CCTA or conventional coronary angiography would be more helpful in various indications. Mean values of the stated assessments are shown ( 1 = conventional coronary angiography much more suitable; 3 = both procedures are of identical value; $5=\mathrm{CT}$ coronary angiography much more suitable).
Abb. 2 Bewertung der Teilnehmer, bei welcher Indikation entweder eine CTA der Koronarien oder eine konventionelle Koronarangiografie als sinnvoller erachtet wird. Es sind die Durchschnittswerte der gegebenen Bewertungen dargestellt ( $5=\mathrm{CT}$-Koronarangiografie wesentlich besser geeignet; 3 = beide Verfahren identisch; 1 = konventionelle Koronarangiografie wesentlich besser geeignet). cians who did not consider the enclosure of relevant images to be of value, and 6 of these stated that the finding alone was sufficient or that the enclosure of images would not significantly affect the therapeutic strategy.

Asked to estimate the cost ratio between CCTA and conventional coronary angiography, 40 of the referring physicians responded. They estimated that conventional angiography was 1.56 times as expensive as CCTA (mean value; median 1.00, range 0.67 - 7.00).

\section{Discussion}

Willingness to participate in our survey, in terms of the actual number of referring physicians who responded, was moderate at $30 \%$. This corresponds to earlier experience in comparable surveys using a written questionnaire [15 - 18]. However, the majority of those willing to participate were physicians who referred an above-average number of patients so that the responses received represented at least $72 \%$ of the referred patients (with an additional unknown number due to the three physicians who responded anonymously).
Only three of the participating physicians had received formal training in the assessment of CCTA. However, in general the physicians were apparently confident in their ability to handle this relatively new procedure, and their assessment of CCTA was largely positive. Thus, in our survey $94 \%$ of the participating physicians assessed the procedure as useful, a figure similar to the $98 \%$ found by Blankstein et al. [19]. However, many referring physicians still chose the more established procedure, with $45 \%$ of them referring their patients for conventional, invasive coronary angiography. In contrast, the patients apparently preferred the noninvasive imaging procedure so that according to the physicians two-thirds of the patients would decide in favor of noninvasive CCTA.

The suitability of the two angiographic procedures for particular indications was in general correctly assessed by the referring physicians: CCTA was considered to be indicated for the exclusion of CHD in cases with low pre-test probability (4.2 on a scale of $1-5)$ and an invasive coronary catheter to be indicated when the pre-test probability was high (2.1 on the same scale) or in cases of suspected acute coronary syndrome (1.6, same scale). Obviously, the referring physicians were aware that conventional angiography has a better accuracy for assessing luminal vessel 
obstruction in stenotic lesions and allows interventional procedures in the same session, whereas CCTA has a high negative predictive value to rule out CHD in patients with a low likelihood of CHD and may avoid a high number of invasive imaging procedures in this patient group. In this context, the physicians regarded CCTA as especially suitable for the exclusion of CHD in the screening of clinically healthy persons (4.5, same scale). This is surprising, not least because in most countries the use of CCTA is at present not allowed for screening, on account of the inevitable exposure of the patient to radiation. Obviously, many physi-

Table 3 Pre-test probability that coronary artery $\mathrm{CT}$ is suitable to detect suspected coronary heart disease as rated by referring physicians and which diagnostic procedures they considered to be necessary before conducting CCTA.

Tab. 3 Prä-Test-Wahrscheinlichkeit, für die die Zuweiser eine CT-Koronarangiografie als geeignet für die Detektion einer koronaren Herzerkrankung erachteten und welche diagnostischen Tests zuvor durchgeführt werden sollten.

\begin{tabular}{|c|c|c|}
\hline \multicolumn{3}{|c|}{$\begin{array}{l}\text { pre-test probability that coronary artery } \mathrm{CT} \text { is suitable to detect } \\
\text { suspected } \mathrm{CHD}^{1}\end{array}$} \\
\hline pre-test probability & number of participant ${ }^{1}$ & percentage \\
\hline below $25 \%$ & 10 & $19 \%$ \\
\hline between $25 \%$ and $50 \%$ & 36 & $68 \%$ \\
\hline between 50 and $75 \%$ & 13 & $25 \%$ \\
\hline above $75 \%$ & 7 & $13 \%$ \\
\hline \multicolumn{3}{|c|}{$\begin{array}{l}\text { diagnostic procedures before conducting CCTA considered to be } \\
\text { necessary in cases of suspected CHD }\end{array}$} \\
\hline diagnostic procedure & number of participants ${ }^{1}$ & percentage \\
\hline resting ECG & 40 & $75 \%$ \\
\hline stress ECG & 31 & $58 \%$ \\
\hline echocardiography & 31 & $58 \%$ \\
\hline stress echocardiography & 20 & $37 \%$ \\
\hline $\begin{array}{l}\text { troponin and CK-MB } \\
\text { determination }\end{array}$ & 15 & $28 \%$ \\
\hline myocard scintigraphy & 7 & $13 \%$ \\
\hline
\end{tabular}

${ }^{1}$ More than one answer could be given; ECG: electrocardiography; CT: computed tomography; CHD: coronary heart disease; CCTA: coronary CT angiography; CK-MB: heart type creatinine kinase cians regard precisely this as a possible application of CCTA. Even today, CCTA can be performed on patients who have sinus rhythm and a heart rate below $<60$ beats/minute, with an average of only $\sim 1 \mathrm{mSv}$ radiation exposure [7]. Further technical development is expected to reduce this dose still further. It is perfectly conceivable that, in the future, continued reduction of the radiation dose will minimize the risk of potentially harmful radiation exposure in comparison with the benefit of the CCTA examination so that CCTA may be offered as a routine screening procedure for CHD.

Reasons stated by the referring physicians for possible unsuitability of a patient for CCTA were given as (above all) the absence of sinus rhythm, claustrophobia, and the fear of exposure to radiation. The absence of sinus rhythm or atrial fibrillation is indeed problematic for 64-line computer-aided tomography in current use. However, these limitations have been taken into account in further technical development so that the newest generation of instruments can also be used with patients whose sinus rhythm is absent and, in some cases, who have atrial fibrillation [20 - 22]. Claustrophobia associated with the instrument is frequently mentioned by patients in surveys [23]. However, the patients are often not aware of the difference between magnetic resonance imaging (MRI) and CT technology, and they cannot distinguish between the narrow gantry and long acquisition time of MRI and the substantially wider gantry and shorter acquisition time (a few seconds only) used in CT. In this context, claustrophobia appears not to be a matter of primary importance associated with CCTA. Nonetheless, modern scanners which allow fast table movement and a sub-second scan time afford higher contrast medium flow rates. These may lead to an even more unpleasant feeling of heat compared to lower injection rates and, from the viewpoint of the patients, may even be of primary importance when assessing the CCTA examination.

Regarding the exposure to radiation that is associated with CCTA, there appears to be confusion among both patients and physicians. Only $42 \%$ of the physicians correctly estimated the radiation exposure associated with acquisition using a 64-row CCTA tomograph. $13 \%$ believed that it was the same as that of a chest X-ray, thus underestimating it substantially. A further $36 \%$ esti-
Impression of patients with CCTA reported by referring physicians $(n=38)$

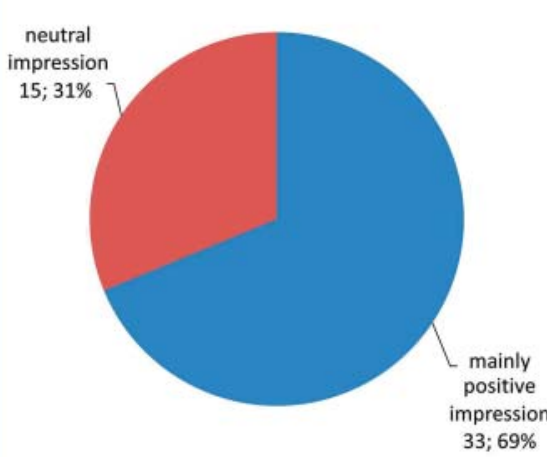

\section{Impression of patients who had previously undergone both conventional coronary angiography and now also CCTA reported by the referring physician $(n=23)$}

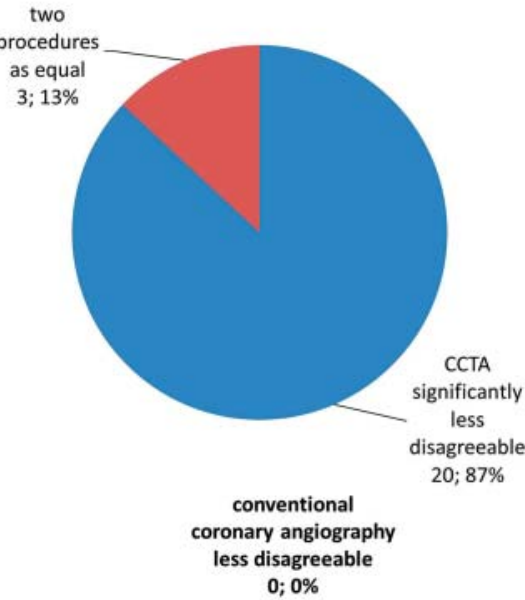

Fig. 3 Impression of patients with coronary CT angiography (CCTA) overall and of patients who had previously undergone both conventional coronary angiography and now also CCTA, reported by the referring physician.

Abb.3 Allgemeiner Eindruck der Patienten von der CT-Koronarangiografie (CCTA) und von Patienten, die zuvor eine konventionelle Angiografie und nun eine CCTA erhalten hatten, jeweils berichtet durch die Zuweiser. 
mated it as corresponding to $\sim 10$ chest X-rays. While this value is still too low for prospectively triggered CCTA, it is correct for the most recent generation of equipment, such as the 320-line CT scanner and the dual-source CT scanner with high pitch factor, which allow a cardiac examination with a radiation exposure of $1 \mathrm{mSv}$ or even less [24, 25].

The patients judged noninvasive coronary angiography positively throughout: $90 \%$ of the referring physicians reported an at least neutral, and mainly positive, assessment by their patients. Particularly clear was the better assessment of CCTA in the intra-individual comparison: $87 \%$ of the physicians reported that noninvasive CCTA was experienced by patients who had undergone both examination procedures as significantly less disagreeable than the conventional procedure with a cardiac catheter. This is in accordance with the findings of a survey by Schönenberger et al. [26], in which patients described CCTA as more agreeable than cardiac MRI and as less painful than invasive coronary angiography.

CCTA has in many studies been found to have a very high negative predictive value for the absence of coronary stenoses [4]. In Germany, where the number of catheter-aided examinations is in any case very large compared with the size of the population, it may be assumed that there is a substantial number of purely diagnostic conventional coronary angiographies with an only very low pre-test probability of an intervention being needed. In addition to the non-negligible radiation risk, there is the danger of local vascular complications at the inguinal puncture site such as aneurysms, arteriovenous fistulae or artery dissection. Our survey of referring physicians showed that this is also reflected in daily therapeutic practice, where for example $34 \%$ of the physicians estimated the number of patients for whom conventional angiography could be dispensed with after CCTA as being between $20 \%$ and $40 \%$, while $17 \%$ of physicians estimated this number as being between $40 \%$ and $60 \%$, and a further $9 \%$ even as being between $60 \%$ und $80 \%$. Moreover, our survey revealed a concrete effect on changes in patient management, whereby nearly one-half of the referring physicians (44\%) estimated the percentage of patients who needed conventional angiography after CCTA as less than $5 \%$.

Regarding the finding, the physicians appeared to have clear expectations. A substantial majority wanted to receive additional material with significant findings, with the additional purpose of being able to explain the findings to their patients more easily and to make the need for treatment clearer to them.

The estimation of the ratio of the costs of the two procedures deviated considerably from the usual current reimbursement figures. A study in the Netherlands found the actual cost of an invasive coronary angiography to be about $€ 1300$ [27]. Although no figures from cost micro-analyses of CCTA are available for Germany, such costs are supposed to be much lower. Moreover, with the indication to rule out CHD in patients with a low pre-test probability of CHD, substantial savings are possible when CCTA is used instead of invasive catheter angiography. In this context the actual amount reimbursed, which is not uniform throughout Germany, should be examined critically. This often fails to cover the center's factual expenses. For patients in the state insurance system, CCTA can often only be invoiced at the rate for simple CT of the chest, despite the fact that the procedure is associated with much more extensive patient information including explanation of the procedure, the administration of a beta-blocker, the use of the newest scanning technology and the necessary special training of technical staff.
A limitation of the present study is the possible bias potentially introduced by the fact that - as in all questionnaire-based surveys - the participants did not comprise the entire population of referring physicians. It is conceivable that physicians might be more motivated to take part if they were either very satisfied or very dissatisfied with the CCTA scans offered. Moreover, only those physicians were consulted who actually did use, and had requested, CCTA.

In summary, it can be stated that noninvasive CCTA, as a still relatively new diagnostic procedure, was on the whole regarded positively by the referring physicians, and their patients found it less disagreeable than invasive coronary angiography. As most of the physicians had not received any formal training in the technique and the interpretation of CCTA, it will be necessary in the future to provide more detailed information about, and guidance in, its numerous possibilities.

\section{References}

1 Budoff MJ, Dowe D, Jollis JG et al. Diagnostic performance of 64-multidetector row coronary computed tomographic angiography for evaluation of coronary artery stenosis in individuals without known coronary artery disease: results from the prospective multicenter ACCURACY (Assessment by Coronary Computed Tomographic Angiography of Individuals Undergoing Invasive Coronary Angiography) trial. Journal of the American College of Cardiology 2008; 52: 1724-1732

2 Meijboom WB, van Mieghem CA, Mollet NR et al. 64-slice computed tomography coronary angiography in patients with high, intermediate, or low pretest probability of significant coronary artery disease. Journal of the American College of Cardiology 2007; 50: 1469-1475

3 Schuetz GM, Zacharopoulou NM, Schlattmann P et al. Meta-analysis: noninvasive coronary angiography using computed tomography versus magnetic resonance imaging. Annals of internal medicine 2010; 152: $167-177$

4 Mowatt G, Cook JA, Hillis GS et al. 64-Slice computed tomography angiography in the diagnosis and assessment of coronary artery disease: systematic review and meta-analysis. Heart (British Cardiac Society) 2008; 94: 1386 - 1393

5 Miller JM, Rochitte CE, Dewey $M$ et al. Diagnostic performance of coronary angiography by 64-row CT. N Engl J Med 2008; 359: 2324-2336

6 Vanhoenacker PK, Heijenbrok-Kal MH, Van Heste R et al. Diagnostic performance of multidetector CT angiography for assessment of coronary artery disease: meta-analysis. Radiology 2007; 244: 419-428

7 Achenbach S, Goroll T, Seltmann $M$ et al. Detection of coronary artery stenoses by low-dose, prospectively ECG-triggered, high-pitch spiral coronary CT angiography. JACC Cardiovascular imaging 2011; 4: $328-337$

8 Zimmermann E, Dewey M. Whole-heart 320-row computed tomography: reduction of radiation dose via prior coronary calcium scanning. RoFo 2011; 183: 54-59

9 Grieve FM, Plumb AA, Khan SH. Radiology reporting: a general practitioner's perspective. Br J Radiol 2010; 83: 17-22

10 Stillman AE, Rubin GD, Teague SD et al. Structured reporting: coronary CT angiography: a white paper from the American College of Radiology and the North American Society for Cardiovascular Imaging. Journal of the American College of Radiology: JACR 2008; 5: 796-800

11 Raff GL, Abidov A, Achenbach $S$ et al. SCCT guidelines for the interpretation and reporting of coronary computed tomographic angiography. Journal of cardiovascular computed tomography 2009; 3: $122-136$

12 McLoughlin RF, So CB, Gray RR et al. Radiology reports: how much descriptive detail is enough? Am J Roentgenol Am J Roentgenol 1995; 165: 803-806

13 Hall FM. Language of the radiology report: primer for residents and wayward radiologists. Am J Roentgenol Am J Roentgenol 2000; 175: $1239-1242$

14 Boynton PM, Greenhalgh T. Selecting, designing, and developing your questionnaire. BMJ 2004; 328: 1312 - 1315

15 Maurer MH, Hamm B, Dewey M. Survey regarding the clinical practice of cardiac CT in Germany: indications, scanning technique and reporting. RoFo 2009; 181: 1135-1143 
16 Johnson PT, Eng J, Pannu HK et al. 64-MDCT angiography of the coronary arteries: nationwide survey of patient preparation practice. Am J Roentgenol Am J Roentgenol 2008; 190: 743 - 747

17 Kubik-Huch RA, Rexroth M, Porst R et al. Wie zufrieden sind die klinischen Partner mit der Arbeit eines radiologischen Instituts? RoFo 2005; 177: 429-434

18 Maurer M, Zimmermann E, Schlattmann P et al. Indications, imaging technique, and reading of cardiac computed tomography: survey of clinical practice. Eur Radiol 2012; 22: 59-72

19 Blankstein R, Murphy MK, Nasir K et al. Perceived usefulness of cardiac computed tomography as assessed by referring physicians and its effect on patient management. The American journal of cardiology 2010; 105: $1246-1253$

20 Vorre MM, Abdulla J. Diagnostic accuracy and radiation dose of CT coronary angiography in atrial fibrillation: systematic review and meta-analysis. Radiology 2013; 267: 376-386

$21 \mathrm{Xu} \mathrm{L}$, Yang $L$, Zhang $Z$ et al. Prospectively ECG-triggered sequential dual-source coronary $C T$ angiography in patients with atrial fibrillation: comparison with retrospectively ECG-gated helical CT. Eur Radiol 2013; 23: $1822-1828$
22 Xu L, Yang L, Fan Z et al. Diagnostic performance of 320-detector CT coronary angiography in patients with atrial fibrillation: preliminary results. Eur Radiol 2011; 21: 936-943

23 Bangard C, PaszekJ, Berg F et al. MR imaging of claustrophobic patients in an open 1.0T scanner: motion artifacts and patient acceptability compared with closed bore magnets. Eur J Radiol 2007; 64: 152 - 157

$24 \mathrm{Yin}$ WH, Lu B, Hou ZH et al. Detection of coronary artery stenosis with sub-milliSievert radiation dose by prospectively ECG-triggered highpitch spiral CT angiography and iterative reconstruction. Eur Radiol 2013; 23: $2927-3293$

25 Chen MY, Shanbhag SM, Arai AE. Submillisievert median radiation dose for coronary angiography with a second-generation 320-detector row CT scanner in 107 consecutive patients. Radiology 2013; 267: 76 - 85

26 Schönenberger E, Schnapauff D, Teige F et al. Patient acceptance of noninvasive and invasive coronary angiography. PLoS 2007; 2: e246

27 Tan SS, Oppe M, Zoet-Nugteren SK et al. A microcosting study of diagnostic tests for the detection of coronary arterydisease in The Netherlands. Eur J Radiol 2009; 72: 98-103 